\title{
Evidence of Sequence and Age of Ancestral Lake Erie Lake-Levels, Northwest Ohio
}

TIMOTHY G. FISHER, Department of Environmental Sciences, University of Toledo, OH, USA; JOSEPH D. BLOCKLAND, Department of Environmental Sciences, University of Toledo, OH, USA, North Dakota Geological Survey, Bismarck, ND, USA; BRAD ANDERSON, Department of Environmental Sciences, University of Toledo, OH, USA, Nyrstar Tennessee Mines, Gordonsville, TN, USA; DAVID E. KRANTZ, Department of Environmental Sciences, University of Toledo, OH, USA; DONALD J. STIERMAN, Department of Environmental Sciences, University of Toledo, OH, USA; RONALD GOBLE, Department of Earth and Atmospheric Sciences, University of Nebraska at Lincoln, Lincoln, NE, USA

\begin{abstract}
While the general scheme of the retreat of the Late Wisconsinan glacier from the ancestral Lake Erie basin is understood, the sequence and timing of those movements that caused lake-level changes are not well documented. Ground penetrating radar (GPR), electrical resistivity (ER), and optically stimulated luminescence (OSL) techniques were used to analyze beach and sand dune formations in the Wauseon area in northwest Ohio. The beaches showed no evidence of being flooded after deposition. Thirteen (13) new OSL ages revealed a short time of approximately 1000 years (16.9-15.9 ka) for formation of the Maumee, Arkona and Whittlesey shorelines. Evidence supporting the Ypsilanti lowstand in the ancestral Lake Erie basin was not observed within two sequences of glacial lacustrine sediments. The results of OSL dating of sand dunes indicate a period of older activity ( 14-15 ka) and confirmation of previous work that documented activity during the Younger Dryas cold period ( 13-11.5 ka).
\end{abstract}

\section{INTRODUCTION}

The ages and evolution of proglacial lakes in the Lake Erie Basin (Figs. 1, 2) are known in general, but poorly understood in detail. A common element in most reconstructions is cyclic lake levels that are controlled by fluctuating ice margins opening and closing poorly constrained and undated outlets. Large vertical variability of lake level through the history of ancestral Lake Erie (ALE) is referred to here as the 'cyclic' model (black line, Fig. 3). Alternatively, from detailed sedimentologic and geomorphic work on a sequence of beaches in northeastern Ohio, Totten (1985) proposed a regular sequence of lake-level fall, also known as the 'episodic' model (gray line, Fig. 3). The chronologies for ice-margin positions and for occupation of shorelines are based on little age data.

The cyclic model was championed by Leverett and Taylor (1915), who noted that some beaches appeared "washed", implying submergence after deposition (i.e., beaches were transgressed over). In this case, a higherelevation beach may be younger than a lower-elevation beach. Fine-grained sediments found on some beaches also have been described and used as evidence for

${ }^{1}$ Address correspondence to Timothy G. Fisher, Mail Stop 604, University of Toledo, Department of Environmental Sciences, Toledo, OH 43606-3390. E-mail: timothy.fisher@utoledo.edu submergence. However, the lower-elevation outlets required to produce early lake-level low phases have not always been observed. This lack of direct evidence has sometimes been explained by subsequent covering of those low outlets by a glacial readvance (Leverett and Taylor 1915). Totten (1985) suggested that leaching of clay from weathering of shale clasts may explain the presence of some fine-grained sediment within the beach deposits. Others (e.g., Bleuer and Moore 1971) have commented that washed beaches may instead be offshore bars.

Past work proposing the cyclic model of fluctuating water levels in the Erie basin also includes a major lake-level fall referred to as the "Ypsilanti lowstand." The lowstand requires recession of the glacier from the Lake Erie Basin for lake levels to drop at least $100 \mathrm{~m}$ below the Maumee and Arkona shorelines (Fig. 3). Following a readvance of ice into the Lake Erie Basin (Port Huron stade), lake level then rose to the Whittlesey Beach, submerging the Arkona Beach (Figs. 2, 3).

Ice-margin recession in the southern Great Lakes and concomitant development of ALE has received little attention since the publication of The Quaternary Evolution of the Great Lakes (Karrow and Calkin 1985). Additional reviews with little new data include those by Barnett (1992), Lewis et al. (1994), and 


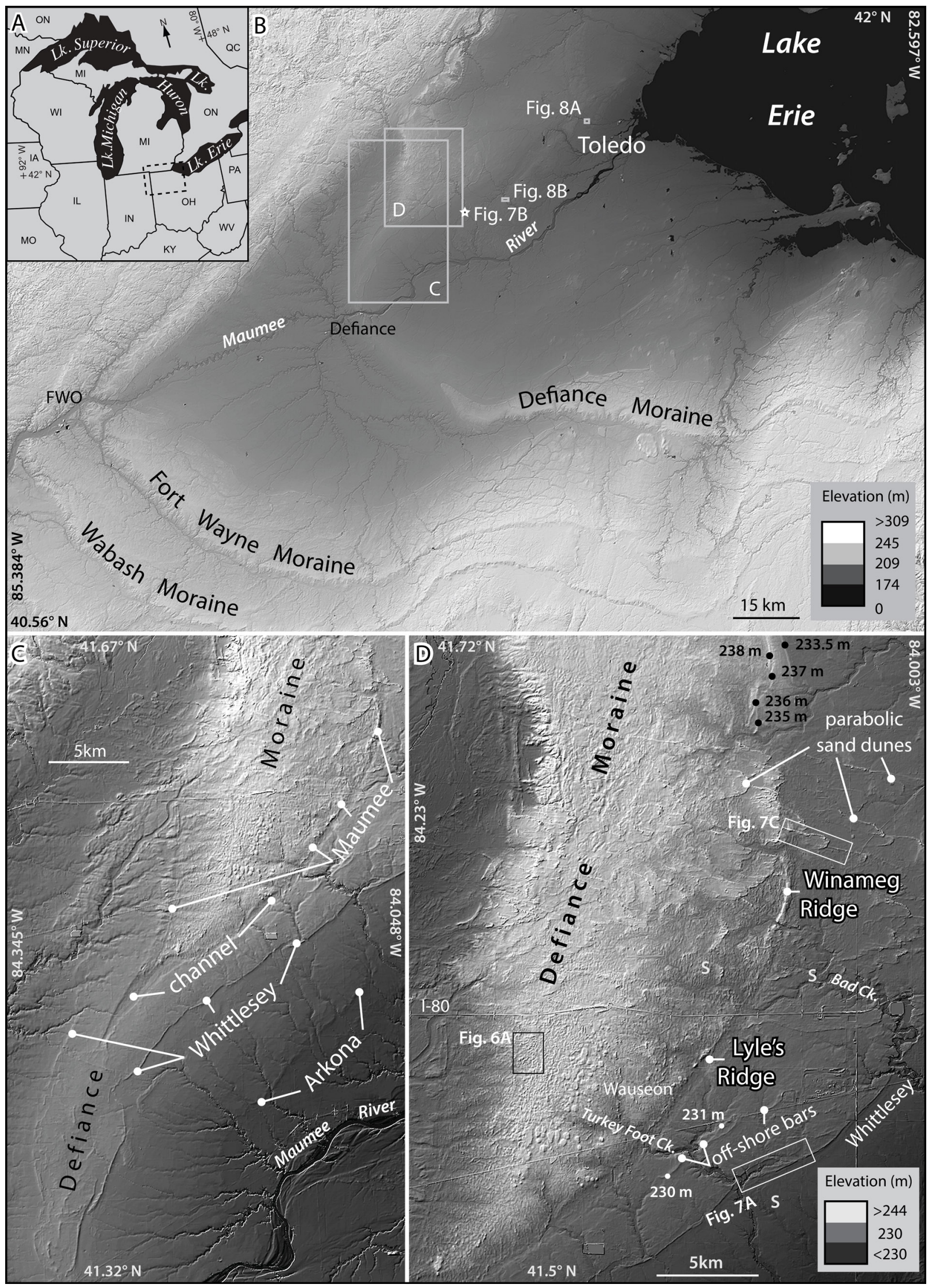

FIGURE 1. Location and digital elevation maps of the study area. A) Study area in northwest Ohio (OH). B) The low-relief Huron-Erie Lake Plain dissected by the Maumee River. At the Maumee level of Ancestral Lake Erie, the lake drained through the Fort Wayne outlet (FWO). The Wabash, Fort Wayne, and Defiance Moraines have been interpreted as recessional positions from the Port Bruce Stade (Fig. 2). Star is location of the Raker cemetery. C) South end of the Defiance Moraine illustrating strandlines and an enigmatic channel parallel to the strandlines. D) Southeast side of the Defiance Moraine with site locations. Numbers with black circles at upper right are elevations of Maumee stage spits. White dots are spot elevations. The S's are locations of Schlumberger soundings. 
Herdendorf (2013). The most recent work has focused on the age of the Warren Beach in northwest Ohio (Campbell et al. 2011; Higley et al. 2014). A general lack of age control and detailed examination of shoreline geomorphology and stratigraphy has hampered more detailed reconstructions of lake history.

One reason for reconstructing ice-margin recession and glacial-lake evolution in the Lake Erie basin is to determine whether there is synchronicity or a lead-lag relationship with Greenland ice-core climate records (Rasmussen et al. 2006). While aeolian activity in northwest Ohio appears to be synchronous with shortlived Greenland stadials (Campbell et al. 2011), not enough data are currently available to determine if icemargin or lake-level changes are similarly synchronous.

The primary purpose of this research is to first test the cyclic model of the Maumee water levels by comparing a "washed" beach to an unwashed beach-specifically, the rise in water level from Maumee II (the washed beach) to Maumee III (Fig. 3). The study took place in the Wauseon area in northwest Ohio and relies on geomorphological and geophysical investigations. In addition, optically stimulated luminescence dating (OSL) was used to date sand dunes associated with the Maumee beaches.

This paper also reports on preliminary testing for the Ypsilanti lowstand; the -100 m lake-level fall with a subsequent transgression. The result of the Ypsilanti lowstand would have been subaerial exposure of the landscape below the Maumee beaches before being flooded at elevations below the Whittlesey beach (Fig. 3). The cyclic model is tested by stratigraphically examining two sedimentary sequences below the Warren Beach, which would have been subaerially

\begin{tabular}{|c|c|c|c|c|c|c|}
\hline $\begin{array}{c}\text { Time } \\
\text { Divisions }\end{array}$ & $\begin{array}{c}\text { Age (ka) } \\
\text { cal. yrs } \\
\text { BP }\end{array}$ & $\begin{array}{l}\text { Age (ka) } \\
{ }^{14} \mathrm{C} \text { yrs } \\
\text { BP }\end{array}$ & $\begin{array}{l}\text { Glacial } \\
\text { Substage } \\
\text { Events }\end{array}$ & $\begin{array}{l}\text { Events in Huron-Erie } \\
\text { Lake Plain }\end{array}$ & $\begin{array}{c}\text { Strand. } \\
\text { Elev. } \\
\text { (m) }\end{array}$ & $\begin{array}{l}\text { Outlets \& } \\
\text { Moraines }\end{array}$ \\
\hline \multirow{7}{*}{ 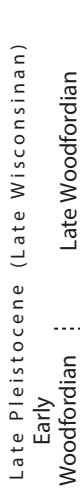 } & \multirow[t]{2}{*}{$\begin{array}{l}14.2- \\
16.0- \\
15.9\end{array}$} & $\begin{array}{l}12.2 \\
13.1 \\
13.0\end{array}$ & $\begin{array}{l}\text { Port Huron } \\
\text { Stade }\end{array}$ & $\begin{array}{l}\text { Lake Lundy } \\
\text { Lake Grassmere } \\
\text { Lake Wayne } \\
\text { Lake Warren (I-III) } \\
\text { Lake Whittlesey }\end{array}$ & $\mid \begin{array}{c}\sim 188 \\
190-195 \\
201 \\
207-203 \\
224\end{array}$ & $\begin{array}{c}\text { East to Mohawk } \\
\text { Valley and/or } \\
\text { west to Grand } \\
\text { Valley } \\
\text { Grand Valley R. }\end{array}$ \\
\hline & & $\begin{array}{l}12.2 \\
13.1 \\
13.0\end{array}$ & Mackinaw Interstade & Lake Ypsilanti & 91 & ? Niagara R. \\
\hline & $\begin{array}{l}16.4- \\
17.6-\end{array}$ & $14.8-$ & $\begin{array}{l}\text { Port Bruce } \\
\text { Stade }\end{array}$ & $\begin{array}{c}\text { Lake Arkona } \\
\text { Lake Maumee (I-IV) } \\
\text { Late Woodfordian Drift } \\
\text { also called, Cary, Hayesville, } \\
\text { Hiram, Lavery, Port-Stanley, } \\
\text { and Lagro Diftt by region. }\end{array}$ & $\begin{array}{l}210-216 \\
232-244\end{array}$ & $\begin{array}{l}\text { Grand Valley R. } \\
\text { Ft. Wayne } \\
\text { Union City- } \\
\text { Defiance } \\
\text { Moraines }\end{array}$ \\
\hline & $18.2-$ & 13.0 & Erie Interstade & Lake Leverett & 178 & Mohawk valley? \\
\hline & $23.4-$ & $19.6-$ & $\begin{array}{c}\text { Nissourian } \\
\text { Stade } \\
\text { max. ice extent }\end{array}$ & $\begin{array}{l}\text { Early Woodfordian Drift } \\
\text { also called Tazewell, Cattish } \\
\text { Creek, Kent, Millbrook, and } \\
\text { Navarre, and Trafalgar Drift } \\
\text { by region }\end{array}$ & & $\begin{array}{l}\text { Hartwell } \\
\text { Moraines }\end{array}$ \\
\hline & $27.0-$ & & Plum Point Interstade & & & \\
\hline & & 2.0 & Cherrytree Stade & Older Drift & & \\
\hline
\end{tabular}

FIGURE 2. Approximate ages and events associated with the HuronErie Lobe. Modified from Howard (2010). exposed during the Ypsilanti lowstand before being resubmerged.

\section{Study area}

The Huron-Erie Lake Plain in northwest Ohio (Fig. 1) was glaciated repeatedly during the Pleistocene (Mickelson et al. 1983) and was last covered by the Laurentide Ice Sheet (LIS) during the Late Wisconsinan Nissourian and Port Bruce Stadials (Calkin and Feenstra 1985, Fig. 2). During the Nissourian Stadial when the glacier reached its maximum position in Ohio, a loamy, stony till was deposited and is commonly referred to as the "Early Woodfordian Drift" (Fig. 2 ). Its upper surface is typically armored by boulders and overlain by clay-rich till generally lacking a high concentration of boulders and cobbles (Forsyth 1960). The clay-rich till deposited during the Port Bruce Stadial is observed in sediment exposures throughout the Huron-Erie Lake Plain (Forsyth 1960) and is referred to as the "Late Woodfordian Drift" in Ohio (Szabo et al. 2011, Fig. 2). The Nissourian and Port Bruce Stadials are separated by the Erie Interstade,

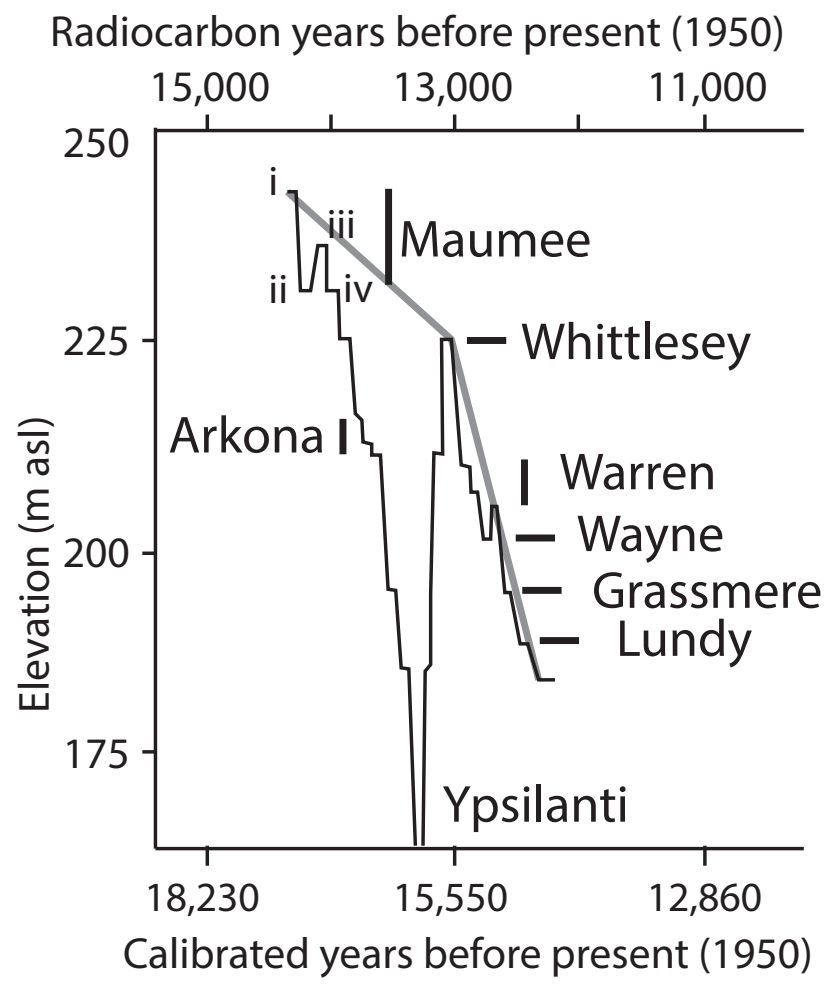

FIGURE 3. Simplified water-level diagram of named beaches in the Lake Erie basin with a radiocarbon age model (top) and calibrated (calendar) age model (bottom). Modified from Calkin and Feenstra (1985).The black line reconstruction requires numerous regressions and transgressions throughout the lake's history ('cyclic' model). Numbers i-iv refer to the different levels of Lake Maumee.'Washing' of the Maumee ii beach is proposed to have occurred as the lake rose to Maumee iii. The gray line is Totten's (1985) proposed simpler lake-level history ('episodic' model). 
explained by the retreat of the glacier northeast of Ohio (Mörner and Dreimanis 1973) and the development of Lake Leverett, a proglacial lake that predates the sequence of the proglacial lakes discussed here. The Erie Lobe may have retreated east as far as the Niagara Escarpment (Dreimanis and Goldthwait 1973). A detailed 1:24,000 surficial geology map of most of the study area is available (Blockland and Fisher 2015).

The major phases of ALE were produced as glacial meltwater and terrestrial runoff ponded between the Fort Wayne Moraine to the west and receding ice margin to the east. Each phase of ALE is referred to as a discrete lake, with the oldest being Lake Maumee (Figs. 2, 3). Four possible levels have been proposed for Lake Maumee between ca. $14,400-13,700{ }^{14} \mathrm{C}$ yrs B.P. (ca. 17, 500-16,900 cal yrs B.P., Fig. 3), but the sequential order in which they formed is unclear (Calkin and Feenstra 1985). Forsyth (1959) and earlier workers used the names Lake Maumee I (ca. $244 \mathrm{~m}$ elevation), II (ca. $232 \mathrm{~m}$ ), III (ca. $238 \mathrm{~m}$ ), and IV (reoccupation of the ca. $232 \mathrm{~m}$ level) to describe the cyclic changes in the Maumee levels inferring the sequential order in which they formed (Fig. 3). Because the sequence of the highstands is unclear, here they are referred to as upper (ca. $244 \mathrm{~m}$ ), middle (ca. $238 \mathrm{~m}$ ) and lower (ca. $232 \mathrm{~m}$ ). The level examined in this research(lower Maumee; II) is interpreted to have been submerged by middle Maumee (Leverett and Taylor 1915) based on its drowned appearance (Forsyth 1959), and because Lake Maumee II was reportedly too low to drain through the higher Fort Wayne and Imlay outlets. However, Bleuer and Moore (1971) later demonstrated that the Fort Wayne outlet was low enough to have drained all levels of Lake Maumee, eliminating the need for a buried outlet.

With continued eastward retreat of the Erie Lobe, ice either paused or readvanced to construct the Defiance Moraine (Fig. 1). However, its formation and timing remain uncertain, with Howard (2010) suggesting that the WNW margin of the Defiance Moraine north of the Maumee River was deposited by the Huron Lobe section of the undifferentiated Huron-Erie Lobe. The strandlines under study are found on the eastern side of the Defiance Moraine.

During the Mackinaw Interstade, a post-Arkona, pre-Whittlesey low-water lake phase, known as Lake Ypsilanti (Figs. 2, 3) formed due to eastward drainage into the Lake Ontario basin. The case for the Ypsilanti lowstand is summarized by Calkin and Feenstra (1985), but evidence supporting it was not observed in northeast Ohio by Totten (1985). Here, we evaluate additional evidence related to a possible Ypsilanti lowstand in northwest Ohio.

\section{MATERIALS AND METHODS Ground penetrating radar (GPR)}

A Sensors and Software pulseEKKO 100 GPR unit was used to collect continuous, high-resolution imagery of primarily sandy, near-surface sediments. Data collected with both $100-\mathrm{MHz}$ and $50-\mathrm{MHz}$ antennas were processed with the EKKO View and EKKO View Deluxe programs. Data processing followed procedures in Higley et al. (2014); for more information on GPR methodology see Jol and Bristow (2003).

\section{Electrical resistivity (ER) \& Schlumberger sounding}

To image through clay-rich sediment, an Advanced Geoscience Incorporated (AGI) Supersting R1/IP resistivity unit with a 28-channel Swift automatic multi-electrode cable was used to constrain sediment stratigraphy in the absence of natural exposures. The system was deployed in the dipole-dipole configuration (see Sheriff 1989, Fig. 9.5) with an electrode spacing of $3.0 \mathrm{~m}$. One feature of AGI's automatic switching system is its use of all available larger a-spacings, which allows deeper penetration. Measurements were inverted using AGI's EarthImager 2D software (Version 2.4.0; 2004; Interpex 2010).Auger and drill borings, and shallow pits allowed us to directly observe sediment to verify geophysical interpretations for both the GPR and ER. The same system was used to take Schlumberger soundings.

\section{Outcrop and Lab}

The stratigraphy at sites in the Wildwood Metropark (WM) and Oak Openings Metropark (OM) (Fig. 1B and 8) was logged in the field. Vertical slices of the exposed sediment were cut from the face, supported in PVC tubes cut lengthwise, and then examined in the lab. After partial drying, the cores were photographed and magnified so that the number of rhythmites could be counted. Particle size was measured by laser diffraction with a Malvern Mastersizer 2000. The loss-on-ignition technique to determine organic and carbonate content followed procedures outlined by Heiri et al. (2001). A Bartington MS2E surface scanning sensor was used to determine magnetic susceptibility of cores at one-half $\mathrm{cm}$ intervals. Hand augering was used to $3.7 \mathrm{~m}$ depth where diamicton was observed at stream level in WM. 
At the OM site, vibracoring (Fisher 2004) was used to collect cores of the rhythmites below stream level. Basal refusal of the vibracore was assumed to indicate the contact between diamicton and lake sediments as determined from hand augering.

\section{LiDAR}

The high resolution light detecting and ranging (LiDAR) data for digital elevation models (DEM) is from the Ohio Geographically Referenced Information Program (OGRIP). DEMs were given 5X vertical exaggeration and hillshaded using Natural Scene Designer software, and lit from $315^{\circ}$ declination at $25^{\circ}$ altitude.

\section{Optically stimulated luminescence}

Optically stimulated luminescence (OSL) dating followed the procedures of Aitken (1998). Field samples were collected from hand-dug soil pits along the crest of sand dunes or hummocks as shown on LiDAR images. Samples were processed at the Luminescence Geochronology Laboratory at the University of Nebraska-Lincoln. For details of sampling and sample preparation see supplementary information from Campbell et al. (2011). OSL samples were analyzed on Riso Automated OSL Dating System Models TL/ OSL-DA-15B/C and TL/OSL-DA-20, equipped with blue and infrared diodes, using the single aliquot regenerative dose (SAR) technique (Murray and Wintle 2000) for determination of the equivalent dose (De) with early background subtraction used (Ballarini et al. 2007; Cunningham and Wallinga 2010). Preheat $\left(240^{\circ} \mathrm{C} / 10 \mathrm{~s}\right)$ and cutheat $\left(220^{\circ} \mathrm{C} / 0 \mathrm{~s}\right)$ temperatures were based upon preheat plateau tests between $180^{\circ}$ and $280^{\circ} \mathrm{C}$. Dose-recovery and thermal transfer tests were conducted (Murray and Wintle 2003). Growth curves were examined to determine whether the samples were below saturation $\left(\mathrm{D} / \mathrm{D}_{\mathrm{o}}<2\right.$; Wintle and Murray 2006). Equivalent dose distributions are based upon a minimum of 50 aliquots (Rodnight 2008). Individual aliquots were monitored for insufficient count-rate, poor quality fits (i.e., large error in the equivalent dose, $\mathrm{D}_{\mathrm{e}}$ ), poor recycling ratio, strong medium vs. fast component (Durcan and Duller 2011), and detectable feldspar. Aliquots deemed unacceptable based upon these criteria were discarded from the data set prior to averaging. Calculation of sample $\mathrm{D}_{e}$ values was carried out using the Central Age Model (Galbraith et al. 1999). However, the $D_{e}$ distribution for UNL3637 (asymmetric distribution; decision table of Bailey and Arnold 2006), indicated that the Minimum Age Model (Galbraith et al. 1999) was more appropriate. Dose rate was calculated by high-resolution gamma spectroscopy, and cosmic component of the dose rate following Prescott and Hutton (1994).

\section{RESULTS AND INTERPRETATION Geomorphology \\ Winameg ridge. The lineation that includes} Winameg and Lyle's ridges (Fig. 1D) was most recently mapped as a washed beach on the lower Maumee shoreline by Forsyth (1959). Winameg ridge is ca. 4 $\mathrm{km}$ long and ca. $200 \mathrm{~m}$ wide for most of its length, except at its bulbous southern end where the spit platform was mined for aggregate (Fig. 4A). The land surface west of the ridge is generally lower by $-5 \mathrm{~m}$ and has hummocky ridges with $<2$ m relief. Earlier excavations on the west side of the ridge revealed a mastodon within pond sediments, but no age control was available for the site (Camp 1981). Further west, parabolic sand dunes and thin sheet sands mask the hummocky terrain (Fig. 4A). The relief east of the ridge is mostly flatter than the hummocky terrain to the west. Numerous parabolic sand dunes have migrated across this surface, which also has some gently arcuate ridges composed of sand and gravel (labeled 'off-shore bars' in Fig. 1D). Rectangular segments revealed by LiDAR imagery at the cemetery and other places along Winameg ridge indicate some minor $(<1 \mathrm{~m})$ modification of the ridge surface.

The combination of ER and GPR surveys provides information about the thickness and nature of the sediment associated with Winameg ridge (Blockland 2013). The 81-m long ER survey parallel to the ridge crest (ER1, Fig. 4A) revealed $-3 \mathrm{~m}$ of highly resistive, flat-lying sediment sharply overlying very low resistive sediment (Fig. 5A). A GPR transect parallel to this ER survey (Fig. 4A, GPR1) revealed flat-lying, continuous to discontinuous reflections parallel to the surface that also end abruptly at 2-3 m depth (Fig. 4C). A GPR transect perpendicular to these surveys shows subparallel, continuous and discontinuous reflections parallel with the surface slope and a localized area of scour and fill centered on $75 \mathrm{~m}$ distance along the transect (Fig. 4D). Sand and pebble gravel between 2 and $4 \mathrm{~m}$ in thickness overlying clay-rich diamicton were collected from auger holes adjacent to the geophysical transects. Another GPR survey (GPR4, Figs. 4A, 5C) along the east slope of the ridge contained mostly subparallel, hummocky discontinuous reflections. The 
basal reflections do not have a sharp contact, suggesting a depth of sand and gravel of about $4 \mathrm{~m}$.

A 630-m long ER survey eastwards from the north end of Winameg ridge (Figs. 4A, 5B) shows the moreresistive sand and gravel pinching out downslope to the east and briefly reappearing beneath an offshore bar at $165 \mathrm{~m}$ distance. At approximately $10 \mathrm{~m}$ below the surface, a more-resistive unit was observed accompanied by a color change from blue to green.
A parallel GPR survey (data not shown) revealed a similar stratigraphy in the first $300 \mathrm{~m}$ (GPR 3a). From 300 to $500 \mathrm{~m}$ distance, the parallel GPR survey was offset $200 \mathrm{~m}$ north (GPR3b), and the few reflections were mostly subparallel, continuous to discontinuous, with some hummocky reflections suggesting infilling of some depressions.

Three Schlumberger soundings were collected from the general area (Fig. 1D) for evaluating the glacial
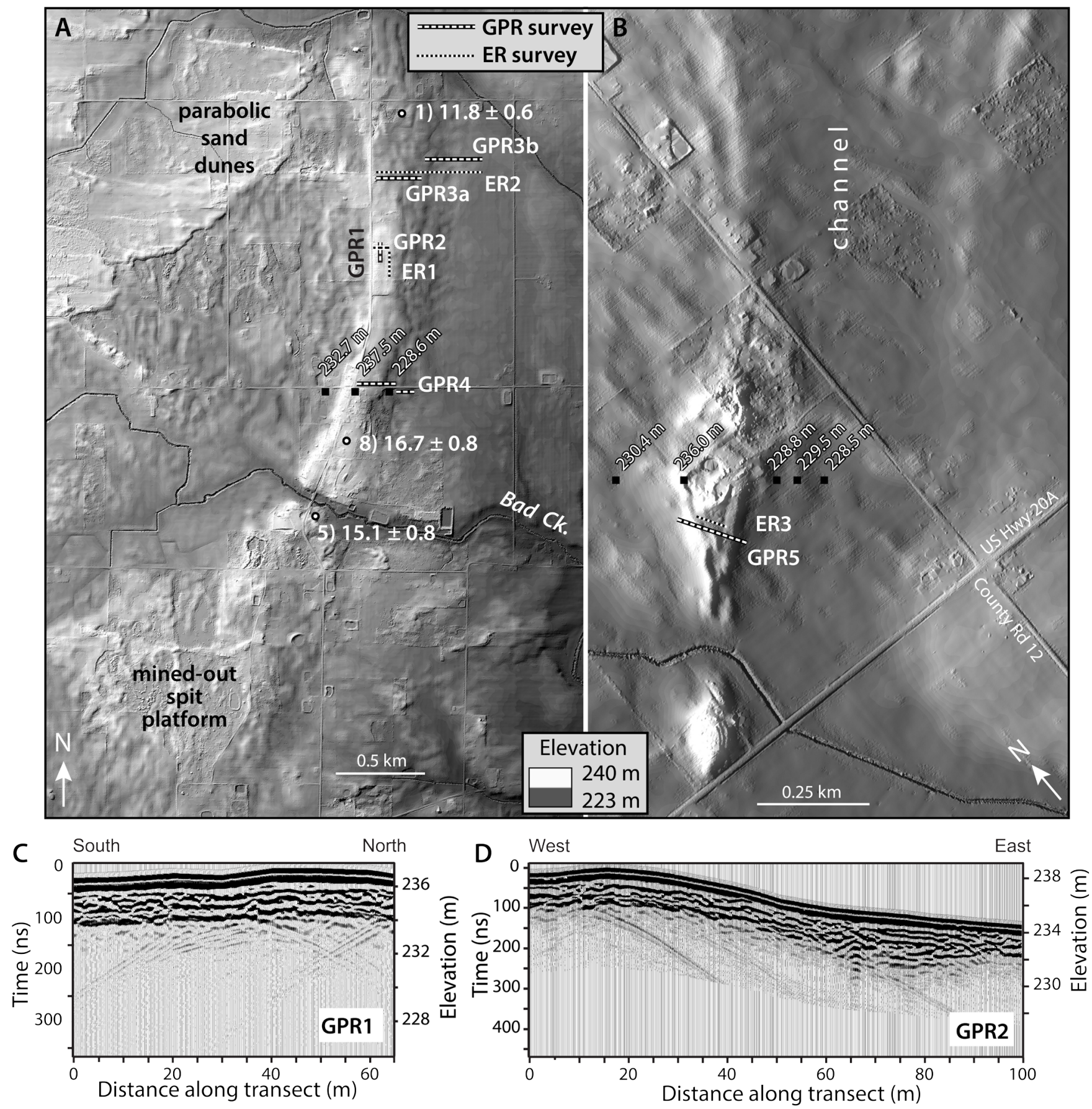

FIGURE 4. LiDAR DEM of A) Winameg ridge and B) Lyle's ridge showing field study sites, OSL ages, and spot elevations (black squares). See Fig. 1D for location of ridges. C) Profile GPR1 along a cemetery road revealing $\sim 3 \mathrm{~m}$ of sand and gravel at the top of the ridge. D) Profile GPR2 crossing GPR1 at $15 \mathrm{~m}$ distance. The thickness of sand and gravel is greater at $75 \mathrm{~m}$ distance within a depression cut into the underlying stratigraphy. 
stratigraphy in detail. At each site the top of a moreresistive unit was encountered between 10 and $11 \mathrm{~m}$ beneath the ground surface. It is hypothesized that this unit is a coarser diamicton equivalent to the Early Woodfordian till, similar to the stratigraphy exposed at the Toledo Edison dam site along the Auglaize River upstream of Defiance, OH (Forsyth 1960) and at Fort Wayne, IN (Bleuer and Moore 1971).

Lyle's ridge. Lyle's ridge is part of the same shoreline lineation and about five $\mathrm{km} \mathrm{SSW}$ of Winameg ridge.
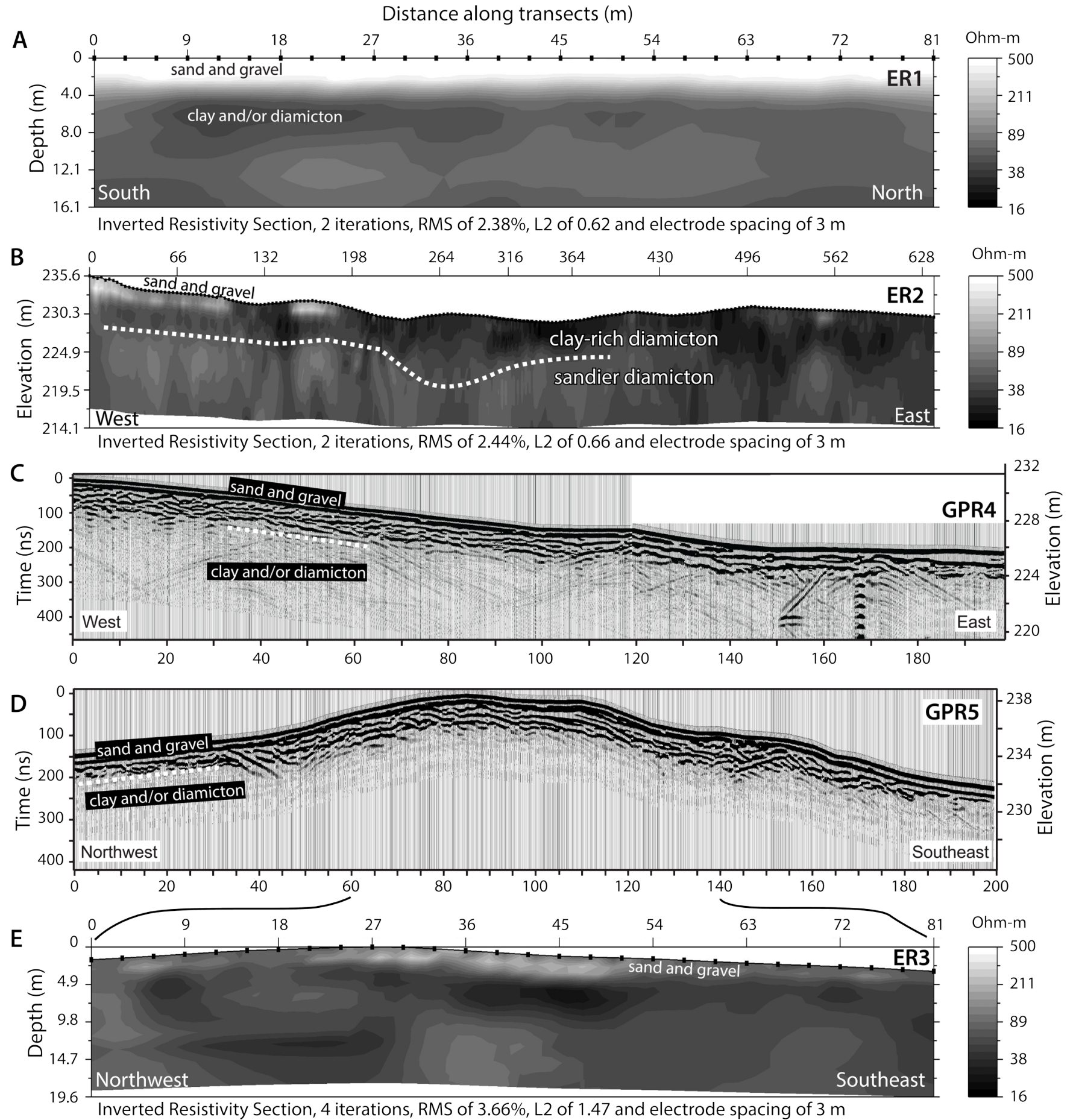

FIGURE 5. Electrical resistivity and ground penetrating radar profiles from Winameg and Lyle's ridges. Locations indicated on Figure 4. A) Profile ER1 along a cemetery road. B) Topographically corrected profile ER2 extending off the east side Winameg ridge onto a washed till plain. Note higher resistive layer at $\sim 10 \mathrm{~m}$ depth that may correspond to a more resistive diamicton. C) Profile GPR4 along east side of Winameg ridge with an approximate thickness of 2 to $3 \mathrm{~m}$ of sand and gravel before the radar signal is attenuated. Road crossed at 118 m. D) Profile GPR5 across Lyle's ridge. E) Profile ER3 across Lyle's ridge collected just north of GPR5. Compare the good correspondence between highly resistive sediment (red) and sand and gravel in (D), and low resistive sediment with lack of penetration by the radar that in auger holes was clay-rich sediment. 
It is approximately $1 \mathrm{~km}$ long and $400 \mathrm{~m}$ wide, and tapers to a point at its southwest end (Figs. 1D, 4B). Two smaller ridges appear north of Lyle's ridge. The top of the northern half of Lyle's ridge has been extensively mined for sand and gravel. The highest point adjacent to the mined-out area is $236 \mathrm{~m}$. An oval-shaped hill to the south is the same elevation as Lyle's ridge.

Immediately to the east of Lyle's ridge, a shallow channel about $1 \mathrm{~km}$ wide with a depth of 2 to $4 \mathrm{~m}$ below the surrounding land surface trends parallel to the lower Maumee shoreline. The channel originates near Winameg ridge and extends to the southwest as a boundary between the hummocky topography of the Defiance Moraine and the relatively flat lake plain below the shoreline. The channel ends to the southwest as a closed depression higher than, and landward of, the Whittlesey shoreline (Fig. 1C).

Diamicton exists at the ground surface on either side of Lyle's ridge and $1 \mathrm{~m}$ below the crest of the ridge immediately south of the GPR transect (Fig. 4B). Other auger holes along the geophysical transects record depths of sand and gravel ranging from $1 \mathrm{~m}$ to greater than $1.5 \mathrm{~m}$. Most of the reflections in the GPR profile across the crest of the ridge are subparallel, discontinuous and hummocky (Fig. 5D). Basal reflections end abruptly, presumably at the contact with diamicton. Some reflections extend more deeply, notably at $40 \mathrm{~m}$ and $145 \mathrm{~m}$ distance. At the southeast end of the transect, the sediment is organic-rich, black mud. The parallel ER transect shows an $-2 \mathrm{~m}$ thick resistive unit (sandier) over more conductive material (siltier) (Fig. 5E), similar to the GPR profile. Based on the ER, GPR and auger holes, Lyle's ridge is interpreted as a veneer of sand and gravel overlying clay-rich diamicton and/or silty clay.

Geophysical and hand augering data from both Winameg and Lyle's ridges document a layer of highly resistive, sandy surface sediment often sharply overlying a low-resistive basal sediment. The subparallel, continuous to discontinuous hummocky and wavy reflections from the GPR are interpreted as aggrading sand and gravel with some cross-bedding, cut and fill sequences, and accumulation of sediment along the east and west sides of the ridges. Auger holes and shallow pits expose the sand and gravel overlying the clay-rich diamicton. In places the thickness of sand and gravel along the ridges is less than the relief of the ridge, and the core of the ridge is diamicton. This suggests that initially the ridges may have had the form of a DeGeer moraine, or hummocks of diamicton.
This is perhaps what is observed on the DEMs west of the ridges, where some hummocks currently are draped by aeolian sand. At the time of deposition of Winameg and Lyle's ridges, this area would have been the shallow shoreface of the early Lake Maumee (Figs. 4A, B). Wave and current erosion of these higher knobs of glacial sediment are likely to have released sand and gravel into the littoral system.

However, this diamicton has proportionately little sand and gravel, so complete reworking of ice-marginal kame deposits may best explain the location and crescentic shape of these landforms. Similarly, the offshore bars east and south of Lyle's ridge (Fig. 1D) that consist of sand and gravel were likely created by reworking of ice-marginal deposits as well. The spit platform and emergent spits on the south side of Winameg ridge indicate a dominant current direction from the north. The Maumee shoreline segments north of Winameg ridge also have asymmetric spit formation indicating net littoral transport to the south and southwest (Fig. 1D).

\section{Age Control}

At present, the different phases of ALE have minimal age control. Radiocarbon ages are often minimum or maximum ages for a given lake level, determined from wood stratigraphically above, or within/beneath the beach, respectively. Here, we present the first OSL ages from the Maumee and Whittlesey shorelines, which directly date deposition of the beach. Aeolian deposits post date the strandlines, and 14 new ages (Table 1) are included to compare with previously collected OSL ages (Campbell et al. 2011; Higley et al. 2014).

Three OSL ages were determined from Winameg ridge (Fig. 4A). One date (sample \#8) comes from fine-to-medium-grained sand interbedded with pebbly gravel from a middle position near the ridge crest. An older (16.7 $\pm 0.8 \mathrm{ka}$; Central Age Model; Galbraith et al. 1999) and younger (12.9 $\pm 0.8 \mathrm{ka})$; Minimum Age Model; Galbraith et al. 1999) age was calculated for UNL3637 because of the equivalent dose distribution (skewness and kurtosis values; Bailey and Arnold 2006). The older age is consistent with other ages on strandline sediment in the study area described later in this section, while the younger age is considered too young for a strandline age based on all previous work on ALE. Further south along the ridge, an age of $15.1 \pm 0.8 \mathrm{ka}$ (sample \#5) is from fine-to-mediumgrained aeolian sand. At the north end, a small ridge composed of aeolian sand that is east of and lower 


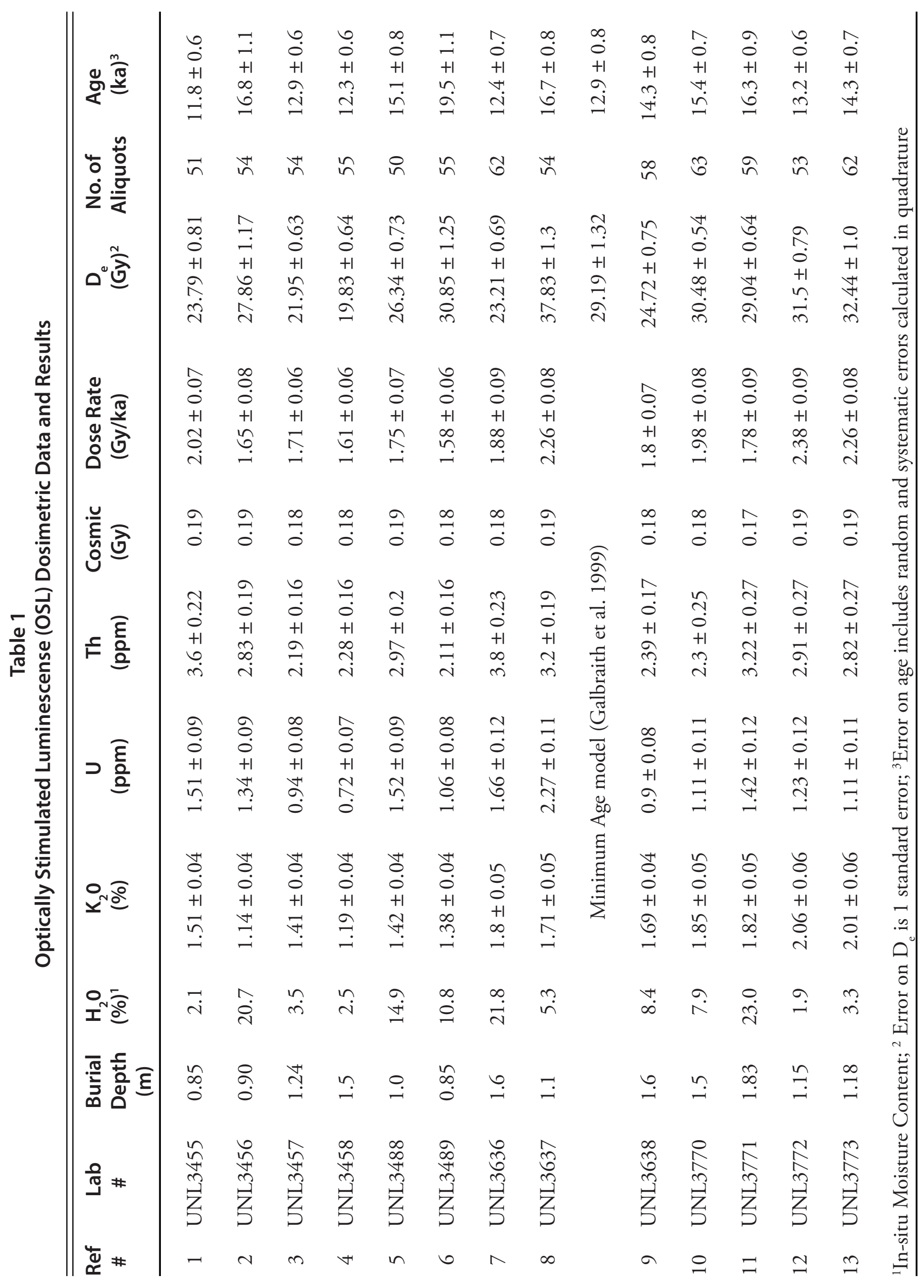


than the main Winameg ridge yielded an age of 11.8 $\pm 0.6 \mathrm{ka}$ (sample \#1).

The hummocky topography northwest of the Town of Wauseon was also investigated to determine the origins and ages of the various hummocks (Figs. 1D, 6A, B). The morphology of the hummocks is varied, with some forming ridges, crescents, and oval-shaped ridges that partially or completely surround a central depression. OSL sample \#6 is from the top of the latter type of hummock, and was collected within dipping, planar-laminated fine sand (Fig. 6C). The resulting age of $19.5 \pm 1.1 \mathrm{ka}$ is considered to be too old because the current deglaciation model (Fig. 2) has this site subsequently overrun by Port Bruce-aged ice. A second sample was collected from the same site (within $-5 \mathrm{~m}$, similar sediments), and resulted in an age of $15.4 \pm 0.7$ ka (sample \#10, Fig. 6A). At a second hummock -100 maway (sample\#11), flat-lying, planar-laminated, fine lacustrine sand was dated at $16.3 \pm 0.9 \mathrm{ka}$.

The $239 \mathrm{~m}$ elevation at these sites is within the elevation range of the higher stands of Lake Maumee. However, the low-centered hummocks are not characteristic of a glacial lake strandline. The land surface south and west of Wauseon has many small ice- walled lake plains; these types of features are generally understood to develop within small lakes in stagnant glacial ice. The rims typically contain sandy or gravelly sediment delivered by meltwater (cf. Curry et al. 2010). The observed sediment may have been deposited in such an environment, and was then deformed as the ice melted to create the dipping beds. If the sediment was deposited in Lake Maumee, it may have been against stagnant ice that subsequently melted out. OSL age \#6 is considered too old and is not discussed further. OSL ages 10 and 11 are considered minimum ages for melting stagnant ice that was presumably coeval with Lake Maumee at this location.

Aeolian sand was encountered at two other hummocks further to the northwest in the same field (Fig. 6A). A sinuous ridge (\#13) with aeolian sand $5 \mathrm{~m}$ thick dated to $14.3 \pm 0.7 \mathrm{ka}$ at its eastern end. A small parabolic dune with sand at least $3.9 \mathrm{~m}$ thick (\#12) was younger, dating to $13.2 \pm 0.6 \mathrm{ka}$. The somewhat crescentic shape of the northern hummock (Fig. 6A) may reflect an incipient sand dune, and the aeolian sand at the northeastern end of the ridge (\#13, Fig. 6A) may simply record deposition of sand in the lee of an older hummock, not unlike deposition of the sheet

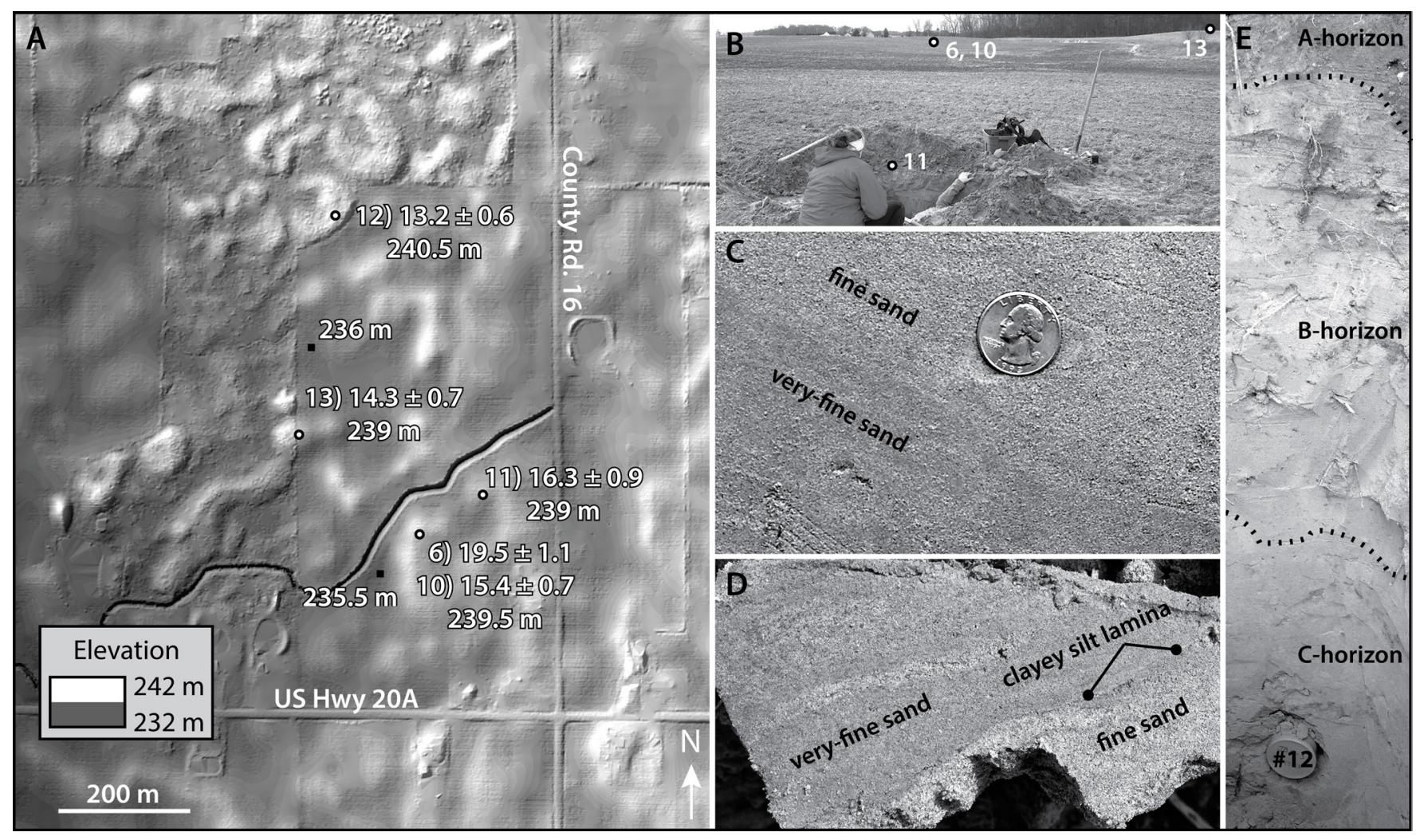

FIGURE 6. Wauseon hummock site. A) LiDAR DEM with spot elevations (black squares) and OSL sample sites (circles) on the light-colored hummocks. B) Ground view (looking southwest) of the hummocks. C) Close-up of fine and very-fine sand from dipping planar laminated sand where sample 10 was collected. D) A block of planar bedded sand from the base of the soil pit where sample 11 was collected. Very thin mud laminae are indicated. E) Soil profile at site 12,1.3 m deep within a parabolic sand dune. Thin clay lamellae are found in the Band C-horizons. Three-inch diameter OSL sample tube 12 labeled. 
sand and parabolic dunes elsewhere on this landscape (northwest corner of Fig. 4A). While detailed landform analysis of the hummocks in Figure 6A is necessary to more precisely determine their origins, the OSL ages can be used to date their final formation.

Two OSL ages are from a Lake Whittlesey spit southeast of Wauseon (Fig. 7A). At the schoolyard site (\#2) much of the spit has been mined away, and the soil pit dug at the base of the slope revealed weakly laminated, lacustrine fine sand over diamicton. The age of $16.8 \pm 1.1 \mathrm{ka}$ is the same as the oldest Winameg ridge OSL age. At the west end of the Whittlesey spit (Fig. 7A), which was partially disturbed by excavations, an age of $12.4 \pm 0.7 \mathrm{ka}$ is from sand, but is too young to be Whittlesey in age and instead may record fluvial deposition from Turkey Foot Creek at this site. A short distance to the northeast of Winameg ridge, a soil pit was dug into the north arm of a parabolic sand dune that exposed a 30-cm thick, weakly developed paleosol of organic-rich sand (Fig. 7C). The ages from below and above this paleosol are $12.9 \pm 0.6 \mathrm{ka}(\# 3)$ and 12.3 $\pm 0.6 \mathrm{ka}(\# 4)$, respectively. At Raker Cemetery south of Delta, $\mathrm{OH}$, an age of $14.3 \pm 0.8 \mathrm{ka}$ comes from a sand dune (Fig. 7B).

\section{Rhythmite Sequence}

At the Wildwood Metropark (WM) exposure (Figs. $1 \mathrm{~B}, 8 \mathrm{~A})$, rhythmites are well exposed for $-100 \mathrm{~m}$ along the south side of a gully (Anderson 2011). Three units in the exposed sequence were measured at a meander cutbank (Fig. 8B). Un-oxidized diamicton is exposed in the stream at the base of the ravine (Fig. 8G). At the study site the diamicton has a minimum thickness of $3.75 \mathrm{~m}$. The diamicton-rhythmite contact undulates along the creek at $186 \mathrm{~m}$ elevation. A pebble count $(n=50)$ resulted in 64 percent carbonates, 20 percent crystalline, and 16 percent clastic pebbles. Abruptly overlying the diamicton was $3.32 \mathrm{~m}$ of rhythmites. The basal rhythmites were dipping and gradually flattened out at about $1 \mathrm{~m}$ above the diamicton. Ripple-form sets (Fig. $8 \mathrm{H}$ ) were observed at various heights in the section. Laminae of 38 couplets were analyzed for particle size. The lighter-colored, moderate pink $(2.5 \mathrm{R} 7 / 6)$ silt laminae $(>3.9-7.8 \mu \mathrm{m})$ alternated with darker grey $(10 \mathrm{YR} 6 / 1)$ silty clay laminae $(<3.9 \mu \mathrm{m})$.

Particle size analysis indicated that the minor sand and clay at the base of the exposure graded to more silt up core. The lighter and coarser laminae have higher values of magnetic susceptibility than the darker and finer-grained laminae where measured on a short section of core. Silt laminae contained less carbonate and more organic material $(2.53$ percent, 0.22 percent, $\mathrm{n}=5$, respectively) than clay laminae (3.55 percent, 0.186 percent, $\mathrm{n}=5$, respectively). Basal contacts of some silt laminae were erosional, in which shallow troughs were cut into underlying silty clay with coarser

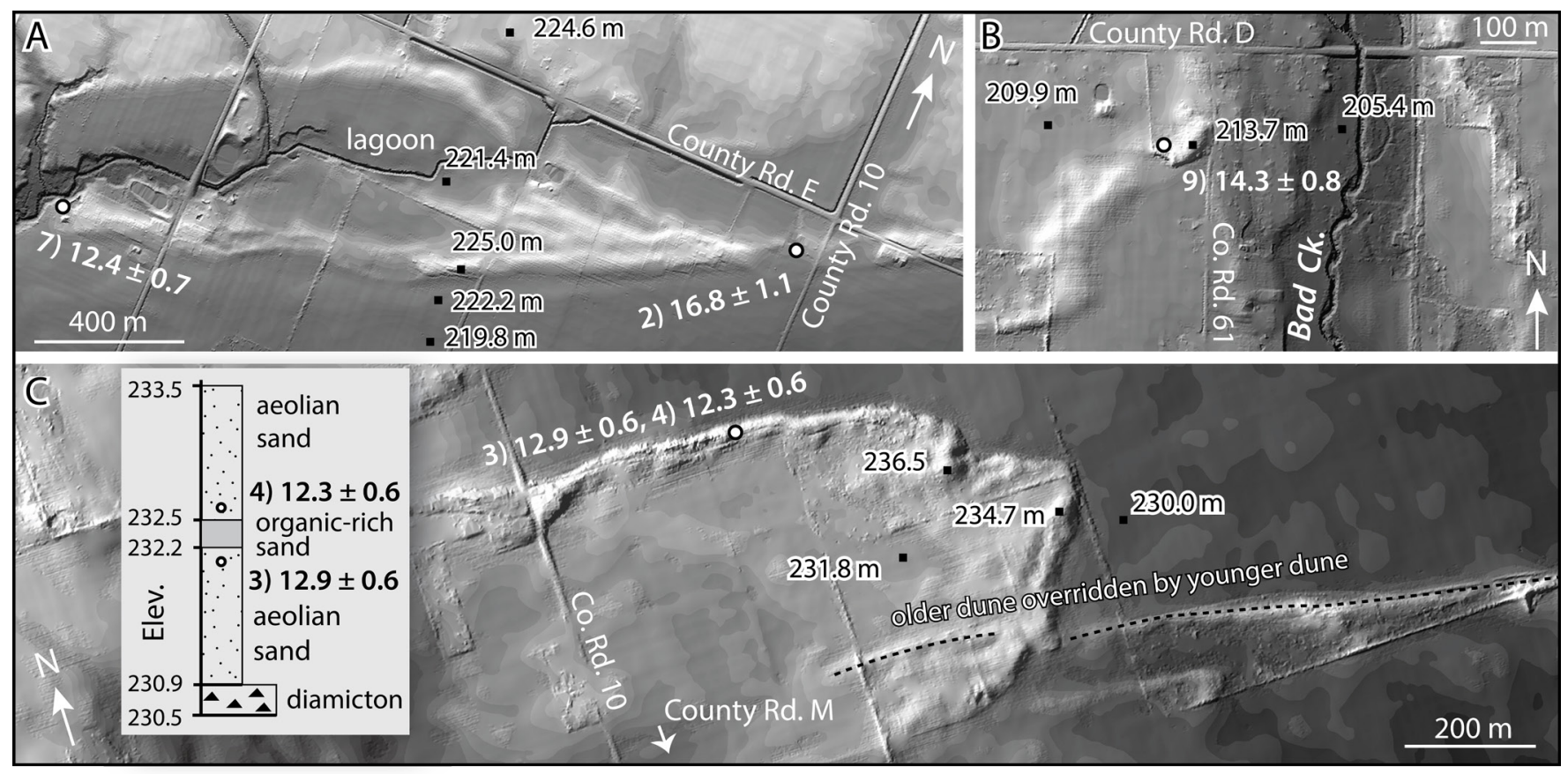

FIGURE 7. Additional study sites in Fulton County (locations on Fig. 1) with age control from OSL dating. Black squares are spot elevations, circles are soil pits where OSL samples were collected, and lighter tones are higher elevations. A) Multi-fingered spit complex of the Whittlesey Beach. B) Raker Cemetery sand dune. C) Large parabolic sand dune that appears to have overridden a smaller, older dune. Lithostratigraphic log inset is from the sample site on the north arm of the dune ridge. 
particles in the base of the trough. Some of the darker laminae had a light speckled appearance (Figs. 8E, F) that in plan view revealed elongate to circular inclusions of silt within clay. The lower contact of the silt was often diffuse or disturbed while the lower contact of the silty clay was usually sharp.

At the WM exposure 483 rhythmites were counted, averaging $0.86 \mathrm{~cm}$ thick. In the lower half of the exposure the finer laminae were thicker, and thinned at the expense of the coarser silt laminae in the upper half of the exposure. Two meters of massive sand unconformably overlie the rhythmites. The sand was not studied in detail and is assumed to be lowershoreface sand associated with Lake Warren or Wayne, or aeolian sand associated with the parabolic dune observed adjacent to the gully (Fig. 8A).

Similar rhythmites were well exposed at the Brown Cut, an -50-m long cutbank exposure in the Oak Openings Metropark (OM) (Fig. 8D). The diamicton recovered from hand augering beneath the rhythmites is massive, clay rich, and gravelly. From the sediment exposure and vibracore, a $4.73 \mathrm{~m}$

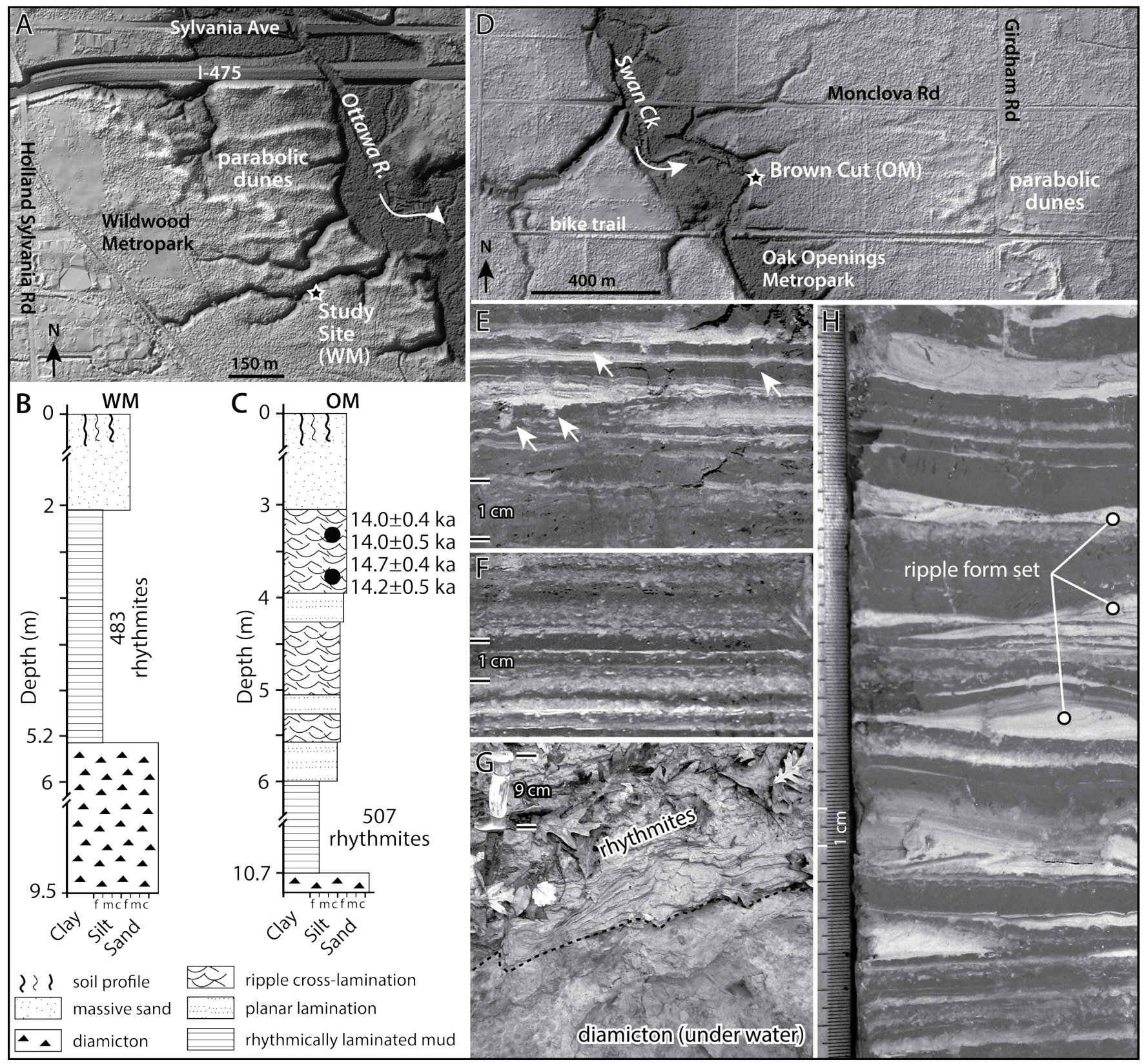

FIGURE 8. Locations of sites, lithostratigraphic logs, and photographs of rhythmites. A) LiDAR DEM of Wildwood Metropark (WM) showing the gully where samples were collected. B, C) Lithostratigraphic logs for the WM and OM study sites, respectively. OSL ages are from Higley et al. (2014). D) Brown Cut along Swan Creek in Oak Openings Metropark (OM). E) Rhythmites from WM with arrows indicating inclusions of light-colored silt within dark-colored silty clay from bioturbation. F) Where bioturbation was extensive at WM, the silt laminae take on a mottled appearance. G) Rhythmites above the level of the stream in the bottom of the gulley at WM, and a stony diamicton viewed through the water. H) While the rhythmites from OM have the same general characteristics as those at WM, they have more ripple-form sets. 
sequence of rhythmites that is overlain by alternating units of finely laminated planar beds of sand and silt with beds of ripple drift and planar laminations was observed. The massive sandy sediments overlying the rhythmites were described recently by Higley et al. (2014) and interpreted as a lower-beachface deposit overlain by aeolian sand. The rhythmites are similar to those described from the WM exposure in that ripple-form sets exist throughout the core (Fig. 8H), increasing in frequency up the section. Rhythmite thickness appears to be controlled by the thickness of the coarser laminae, and 507 couplets were counted.

The sedimentary sequences described from the WM and OM exposures are interpreted as a deglacial sequence of till overlain by glaciolacustrine deposits. This interpretation is based on the massive, clay-rich characteristic of the diamicton that contains erratic stones and is similar to till mapped in northwest Ohio (Larsen et al. 2005) and southeast Michigan (Howard 2010). Presumably, the till was deposited while the glacier was receding eastwards across the Lake Erie basin and in contact with ancestral Lake Erie. While inaccessible at outcrop, some stratification would be expected at the contact between the till and rhythmites. Localized sediment focusing and infilling of irregular topography on the lake floor would explain the undulating contact between the till and dipping rhythmites at WM. Three criteria suggested by Smith and Ashley (1985) support an interpretation of varves: 1) the contact between dark, winter laminae and overlying light ( summer laminae is usually sharp and in places bioturbated); 2) the winter laminae have a relatively consistent thickness; and 3) a decrease in sand (fining) up section. Suspension settling of clay in winter during the non-melt season explains the lower magnetic susceptibility values (Snowball et al. 1999). The mm- to cm-sized scour deposits and silt inclusions within clay (Figs. 8E, F) are interpreted as evidence of bioturbation during the summer season, which would explain the mottled appearance of the darker clay.

Ripple-form sets have been observed within glaciolacustrine deposits in south central Michigan (Fisher and Taylor 2002), and are commonly interpreted as underflow or hyperpycnal deposits (Shaw and Archer 1978). The geographic setting of the study area requires that such flows are supplied from sediment from streams on the west side of the lake and not from meltwater from ice receding to the east. Stream systems incising into recently exposed till and lacustrine sediment may explain the high sediment load required to set up hyperpycnal flows. Alternatively, slumping of sediment around the shoreline may initiate hyperpycnal flows (Shaw and Archer 1978).

If the rhythmites are indeed varves, the count of 507 varves from $\mathrm{OM}$ is a minimum estimate of years of sedimentation. It is likely that some couplets may be underflow deposits, which along with truncated upper contacts at both study sites suggests that the count of 507 is only an estimate. If not varves, then even fewer years are recorded by the rhythmic sediments. Absolute age of the varves is unknown, and they would have been deposited in water depths at WM of -20 $\mathrm{m}$ in Lake Warren, $-25 \mathrm{~m}$ in Lake Arkona, or -38 $m$ in Lake Whittlesey. At the OM site, water depths would have been $-5 \mathrm{~m}$ shallower in each lake. Based on the apparent conformable contact with underlying diamicton at the WM exposure, the rhythmites were deposited in Lake Maumee. The coarsening-upward sequence at the OM exposure indicates that some of the rhythmites likely are associated with Lake Warren, Lake Whittlesey, and perhaps older lakes.

\section{DISCUSSION}

Detailed examination of two segments of the lower Maumee shoreline indicates that these landforms developed as spit complexes associated with a segmented island shoreline rather than as a 'washed' beach. The littoral deposits of Winameg and Lyle's ridges resulted from reworking a hummocky and ridged diamicton surface. During the late Maumee highstand, these glacial deposits were eroded by waves, and sand was transported by currents downdrift to construct shallow spit platforms with low-relief emergent spit ridges. The washed appearance is derived from reworking and smoothing of the initial landforms with deposition of the spit complex in shallow water. Later in the evolution of the area, aeolian mobilization of surficial sand sheets and the migration of parabolic dunes further covered (or draped) the lower Maumee shoreline features.

Overtopping of the lower Maumee shoreline by a subsequent highstand (for example, Maumee II at $232 \mathrm{~m}$ being flooded by Maumee III at $238 \mathrm{~m}$ and reoccupied by Maumee IV at $232 \mathrm{~m}$ ) should have produced several specific geomorphic and stratigraphic results. For example, preservation of the initial shoreline requires an extremely rapid rise of lake level by many meters in a few years. Otherwise, shoreline ravinement during the transgression and erosion 
within the shoreface down to wave base during the highstand would bevel off any pre-existing shoreline. Even if the initial shoreline survived the transgression, the preserved stratigraphy should be dominated by landward transport of eroded sand by overwash and other inlet processes. If this had occurred in the lower Maumee, accommodation space (depressions) in the highstand shoreface would be mostly filled by deposition.

Geophysical evidence of landward migration of sediment within the stratigraphy similar to transgressing modern barrier islands (e.g., Hayes and FitzGerald 2013) was not observed. Nor are there obvious geomorphic features that suggest extensive landward transport in the study area. Instead of overwash lobes and channels, a spit platform with simple ridges at the southern end of Winameg ridge records a short-lived lake level. The spits in the same lineation north of Winameg ridge at 238 to $233.5 \mathrm{~m}$ elevation (Fig. 1D) similarly show dominant littoral transport of sediment from the north within a falling lake level; these shoreline features have relief equivalent to that of Winameg ridge. Classification of Lyle's ridge is more difficult as the thin ridges at its north end are likely sand and gravel, similar to the narrow ridge that was examined in this study. The low-relief ridges (of sand and gravel) just east of Winameg and Lyle's ridges shown on Figure 1D are most likely offshore bars as mapped by Blockland and Fisher (2015).

From this analysis, the "washed" characteristics of the lower Maumee shoreline (II, Fig. 3) simply record syndepositional processes that operated while the lake existed, followed by post-depositional modification by aeolian processes. Without the need for a younger transgression to overtop and drown an older strandline, the reconstruction of Maumee lake levels can be simplified to a sequence in which successively lowerelevation strandlines are progressively younger. This simplified lake-level history favors the episodic model, and is consistent with the findings of Bleuer and Moore (1971) that incision of the Fort Wayne outlet through time could accommodate all of the Maumee levels. Previously, Leverett (1902) assigned elevations of 233.2-231.6 $\mathrm{m}$ to these lower Maumee shoreline ridges, and Forsyth (1959) assigned an elevation of $232 \mathrm{~m}$. There has been uncertainty on what specific landforms were interpreted in the western basin of ALE to indicate past lake levels. Rather than pursuing detailed discussion with past results, the next step forward to understanding lake-level evolution in the western basin of ALE should be based on detailed mapping of individual shorelines to aid water-plane assignments (cf. Fisher 2005; Breckenridge 2015) using the recently released LiDAR data.

Four OSL dates are used to assess the ages of the Maumee and Whittlesey shorelines. The two oldest ages are nearly identical and come from the Maumee and Whittlesey shorelines. The two younger ages are from fine sand associated with low-centered hummocks northwest of Wauseon, but at the same elevation as the Winameg ridge. The precise origin of these hummocks awaits more detailed study, with current hypotheses favoring small ice-walled lake plains, or outwash or littoral sediment deposited on stagnant ice. The hummock ages overlap with the two older ages at one standard deviation, thus an age of $-16.8 \pm 1.0 \mathrm{ka}$ is assigned to the younger Maumee strandline. According to the cyclic model, the Whittlesey shoreline should be much younger if it developed after the Ypsilanti Low. However, OSL date \#2 (Table 1) is the same age as the lower Maumee ridge, which instead favors the episodic model. Alternatively, OSL date \#2 may be from sand that was deposited in Lake Maumee in $-8 \mathrm{~m}$ of water, and lies stratigraphically below the deposits of the Whittlesey strandline. In that case, Lake Whittlesey remains to be dated by OSL. However, according to Calkin and Feenstra (1985) Lake Whittlesey is the best-dated lake in ALE at $\sim 13,000{ }^{14} \mathrm{C}$ yr BP $(-15,900$ cal yr BP), which is within one standard deviation of the OSL ages presented here.

While a Lake Arkona strandline was not dated in this study, Hough (1958) reports an age of 13,600 \pm 500 ${ }^{14} \mathrm{C}$ yr BP (W-33) for it, and Szabo et al. (1988) report an age of "about" $13,400{ }^{14} \mathrm{Cyr}$ BP (ISGS-1480), both of which calibrate to $\sim 16,400$ and $\sim 16,100$ cal yrs BP, respectively. Based on these data of overlapping ages at one standard deviation, there is little time available to form the strandlines of lakes Maumee, Whittlesey and Arkona, and the Ypsilanti lowstand using the cyclic model. A suggested sequence of events is: Maumee to Whittlesey to Arkona, and possibly then the Ypsilanti low (Fig. 9). More OSL dates are required from these beaches to refine the lake-level curve.

Lakes Maumee, Whittlesey and Arkona appear to have developed between 17 and $15 \mathrm{ka}$, before the warm Bølling-Allerød interstadial. In contrast, Lake Warren is well dated at about $14.1 \mathrm{ka}$ (Fig. 9), and developed during the Bølling-Allerød interstadial. The Warren beaches are sandy and are strongly developed throughout the basin (Calkin and Feenstra 1985), 
which may reflect a longer period of time at a relatively stable water level.

The approximately 500 varves from both the WM and OM sites provide some limitations on the deglacial history for the region. The sharp contact from till to lacustrine sediments observed at WM is interpreted as deposition into an ice-contact glacial lake at the receding ice margin. The upper contact of the rhythmites is most likely erosional at both sites, thus the number of rhythmites is a minimum. However, the similar count from both sites and the increase in ripple-form sets towards the top of the sequence at OM suggests shoaling and minimal erosion. Taken together, the evidence suggests: 1) ice-margin recession was much slower out of the basin than previously realized; or 2) a disconformity at the top of the till or within the rhythmite sequence marks a period of time between ice-margin recession (lower rhythmites) and resumed rhythmite deposition as lake level dropped and sediment was supplied from the land (upper rhythmites). Subaerial exposure during the Ypsilanti lowstand would be expected to have generated a weathering profile, an unconformity, and possibly a ravinement surface as a record of the regressiontransgression cycle. No evidence of these sedimentary features was observed along the outcrop or within the core. Supporting evidence for the Ypsilanti lowstand was not observed at sites expected to record such dramatic lake-level changes.

The sand dunes dated in this study were the same age or older than the dunes dated by Campbell et al. (2011) up to $15 \mathrm{~km}$ to the east. With one or two outliers, the sand dunes are progressively younger at lower elevations (Fig. 9). This general relationship is expected when the dunes date back to deglaciation and are concomitant with dropping lake levels, if sediment supply for the dunes is limited. Progressively younger dunes would also be expected when they are remobilized, as indicated by OSL dates 3 and 4 from this study on either side of a paleosol. Eight of the 16 OSL dates on dunes overlap at one sigma error with the Younger Dryas stadial (Fig. 9). It appears that dune activation may be associated with episodic sand availability at the land surface because of either deglaciation controlling lake-level fall, or abrupt climate change, specifically times of reduced vegetative cover associated with regional aridity.

\section{SUMMARY}

Cyclic changes in lake levels of ancestral Lake Erie have been discussed for more than 100 years. The concept of "washed" Lake Maumee shorelines identified as having been submerged by subsequent transgressions can be explained more simply by first

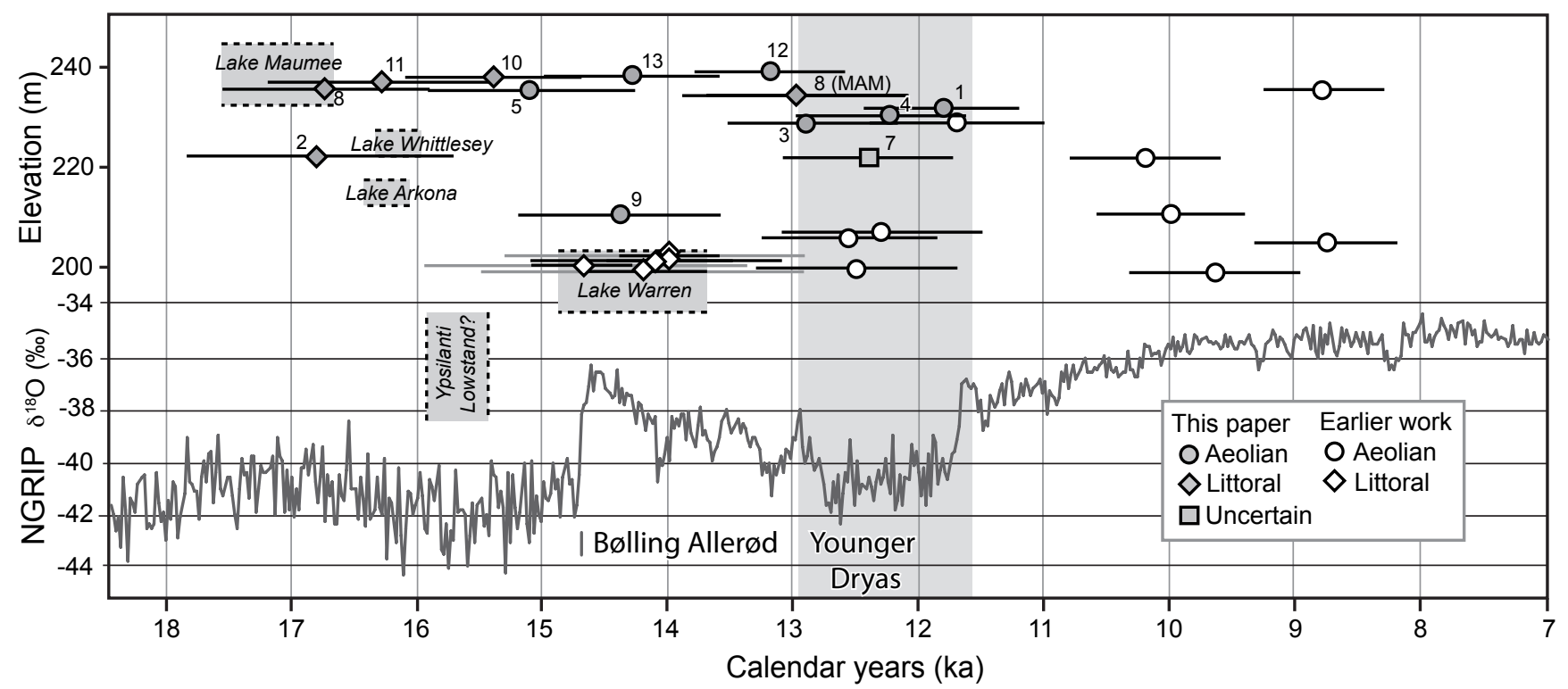

FIGURE 9. Comparison of lake-level events in northwest Ohio with the North Greenland ice-core climate proxy (NGRIP) data (Rasmussen et al. 2006). Earlier work was by Campbell et al. (2011) and Higley et al. (2014). Note that the grey standard deviation lines for the Lake Warren ages reflect age uncertainty by Higley et al. (2014) for comparison with the age reporting convention used by Campbell et al. (2011). The four new ages for the Maumee and Whittlesey Beaches overlap at one standard deviation. Sand dune ages 5, 9, and 13 record earlier aeolian activity than previous studies, indicating that aeolian activity was episodic across this landscape through 6000 years. Five additional dune dates during the Younger Dryas stadial further support earlier work that the timing of Greenland stadials correspond with aeolian activity in northwest Ohio. 
distinguishing between different types of shorelines. Geomorphological analysis and geophysical transects across a "washed" lower Maumee beach and shoreface provided no support for a later transgression and reworking of sediment. Instead, interpreting the landform as a spit formed in shallow water better explains the washed appearance. Extensive mobilization of aeolian sand on and around the ridge also may explain part of the washed appearance. The results of this research support an interpretation of episodic lake-level fall in Lake Maumee with temporary levels — stillstands - controlled by sill elevation at the Fort Wayne outlet.

OSL ages obtained from a Maumee spit, fine sand beneath a Lake Whittlesey spit, and fine sand from low-centered hummocks west of the Maumee shoreline support an age of approximately $16.8 \mathrm{ka}$ for Lake Maumee in the study area. The one OSL date from beneath the Lake Whittlesey spit yields the same age as the Maumee spit, which calls into question whether the Whittlesey is accurately dated with that OSL sample. Radiocarbon ages summarized by Calkin and Feenstra (1985) suggest an age of $15,900 \mathrm{cal} \mathrm{yr}$ BP for Lake Whittlesey and $-16,300 \mathrm{cal}$ yr BP for Lake Arkona. This condensed chronology provides little time for formation of Lake Arkona beaches at elevations between lakes Maumee and Whittlesey, and the Ypsilanti lowstand. It may be possible that the Ypsilanti lowstand is actually younger than the Whittlesey shoreline.

The floating chronology of -500 rhythmites from two exposures stratigraphically below Lake Warren shoreline deposits were expected to show unconformities associated with the Ypsilanti lowstand. However, sedimentary features that would support the Ypsilanti lowstand, such as a weathering profile, an unconformity, and/or a ravinement surface, were not observed between the till and rhythmites, or within the rhythmites.

The additional OSL ages on sand dunes agree with results from Campbell et al. (2011) that many of the dunes were last active during the Younger Dryas stadial. Additional new ages mostly from higher-elevation sand dunes record earlier aeolian activity.

\section{ACKNOWLEDGMENTS}

Field assistance was provided by Mike Angle, Jake Ardner, Kira Baca, Joel Banaszak, Samantha DeWald, Biniam Estifanos, Jennifer Horton, Chris Maike, Susan McCormick, Brendan Poffenbaugh, Steve Ransford,
Kyle Siemer, Heather Stewart and Kirk Zmijewski. Technical assistance was from Richard Becker, Butch Berger, Jamie Martin-Hayden and Jason Witter. Karen Menard is thanked for facilitating access to the Toledo Metro Park sites. Funding was provided from USGS EDMAP grant G11AC20135 to Fisher, and University of Toledo Department of Environmental Sciences Ruedisili fund. The paper was improved by the journal reviewers, and especially from the insight of Dr. Henry Loope.

\section{LITERATURE CITED}

Aitken MJ. 1998. An Introduction to optical dating: The dating of Quaternary sediments by the use of photon-stimulated luminescence. New York: Oxford University Press. 280 p.

Anderson B. 2011. Estimating the duration of ancestral lake Erie using varve analysis at and above the Warren stage in northwest Ohio. [Thesis]. [Toledo $(\mathrm{OH})]$ : University of Toledo.

Bailey RM, Arnold LJ. 2006. Statistical modeling of single grain quartz De distributions and an assessment of procedures for estimating burial dose. Quat. Sci. Revs. 25:2475-2502.

Ballarini M, Wallinga J, Wintle AG, Bos AJJ. 2007. A modified SAR protocol for optical dating of individual grains from young quartz samples. Radiation Measure. 42:360-369.

Barnett PJ. 1992. Quaternary geology of Ontario. In: Thurston PC, Williams HR, Sutcliffe RH, Scott GM, editors. Geology of Ontario. Sp Vol 4. Toronto: Ontario Geological Survey. p. $1010-1088$.

Bleuer NK, Moore MC. 1971. Glacial stratigraphy of the Fort Wayne area and the draining of glacial Lake Maumee. Indiana Acad. Sci. 81:195-209.

Blockland JD. 2013. The surficial geology of Fulton County, Ohio: insight into the Late Pleistocene-Early Holocene glaciated landscape of the Huron-Erie Lake Plain, Fulton County Ohio, USA. [Thesis]. [Toledo $(\mathrm{OH})$ ]: University of Toledo.

Blockland JD, Fisher TG. 2015. The surficial geology of the Delta 7.5 minute series quadrangle, Ohio, USA. J Maps. DOI: $10.1080 / 17445647.2015 .1071289$

Breckenridge A. 2015. The Tintah-Campbell gap and implications for glacial Lake Agassiz drainage during the Younger Dryas cold interval. Quat. Sci. Revs. 117: 124-134.

Camp MJ. 1981. Pleistocene history and molluscan paleoecology of the Winameg mastodon site, Fulton County, OH. Ohio J Sci. 81:230-235.

Calkin PE, Feenstra BH. 1985. Evolution of the Erie-basin great lakes. In Karrow PF, Calkin PE. Eds. Quaternary Evolution of the Great Lakes, Sp. Pap. 30. St. John's: Geological Survey of Canada. p. 149-170.

Campbell MC, Fisher TG, Goble RJ. 2011. Terrestrial sensitivity to abrupt cooling recorded by aeolian activity in northwest Ohio, USA: Quat. Res. 75:411-416.

Cunningham AC, Wallinga J. 2010. Selection of integration time intervals for quartz OSL decay curves. Quat. Geochron. 5:657-666.

Curry BB, Konen ME, Larson TH, Yansa CH, Hackley KC, Alexanderson H, Lowell TV. 2010. The DeKalb mounds of northeastern Illinois as archives of deglacial history and postglacial environments. Quat. Res. 74:82-90. 
Dreimanis A, Goldthwait RP. 1973. Wisconsin glaciation in the Huron, Erie, and Ontario Lobes. Geol. Soc. Am. Mem. 136:71-106.

Durcan JA, Duller GAT. 2011. The fast ratio: A rapid measure for testing the dominance of the fast component in the initial OSL signal from quartz. Radiation Measure. 46:1065-1072.

EarthImager 2004. Earthimager 2D, Version 1.7.7, Advanced Geosciences, Inc., Austin, Texas 78726.

Fisher, TG. 2004. Vibracoring from lake ice with a lightweight monopod and piston coring apparatus. J Paleolimn. 31:377-382.

Fisher TG. 2005. Strandline analysis in the southern basin of glacial Lake Agassiz, Minnesota and North and South Dakota, USA. Geol. Soc. Am. Bull. 117:1481-1496.

Fisher TG, Taylor LD. 2002. Sedimentary and stratigraphic evidence for subglacial flooding, south-central Michigan, USA: Quat. Int. 90:87-115.

Forsyth JL. 1959. The beach ridges of northern Ohio. Ohio Div. Geol. Sur. Info. Circ. 25:1-10.

Forsyth JL. 1960. Correlation of till exposed in the Toledo Edison Dam cut, Ohio. Ohio J Sci. 60:94-100.

Galbraith RF, Roberts RG, Laslett GM, Yoshida H, Olley JM. 1999. Optical dating of single and multiple grains of quartz from Jinmium Rock Shelter, Northern Australia: Part I, experimental design and statistical models. Archaeometry. 41:339-364.

Hayes MO, FitzGerald DM. 2013. Origin, evolution and classification of tidal inlets. J Coast. Res. 69:14-33.

Heiri O, Lotter AF, Lemcke G. 2001. Loss on ignition as a method for estimating organic and carbonate content in sediments: reproducibility and comparability of results. J Paleolimnol. 25:101-110.

Herdendorf CE, 2013. Research overview: Holocene developments of Lake Erie: Ohio J Sci. 112:24-36.

Higley MC, Fisher TG, Jol HM, Lepper K, Martin-Hayden JM. 2014. Stratigraphic and chronologic analysis of the Warren Beach, northwest Ohio, USA. Can. J Earth Sci. 51:737-749.

Howard JL. 2010. Late Pleistocene glaciolacustrine sedimentation and paleogeography of southeastern Michigan, USA: Sed. Geol. 223:126-142.

Hough JL. 1958. Geology of the Great Lakes. Urbana, Illinois. University of Illinois Press. 334 p.

Interpex 2010. Interpex, Inc. Golden, Colorado 80402 user manuals for the $1 \mathrm{X} 1 \mathrm{D}$ at http://www.interpex.com/ix1d/ ixld.htm

Jol HM, Bristow CS. 2003. GPR in sediments: advice on data collection, basic processing and interpretation, a good practice guide. In Bristow CS, Jol HM, editors. Ground Penetrating Radar in Sediments. London: Geol. Soc. London. 211:9-27.

Karrow PF, Calkin PE. 1985. Quaternary Evolution of the Great Lakes. St. John's: Geological Survey of Canada. Sp. Pap. 30. 258 p.

Larsen GE, Shrake L, Swinford EM. 2005. Surficial geology of the Ohio portion of the Toledo $30 \times 60$-minute quadrangle. Ohio Division of Geological Survey Maps SG-2 Toledo, $1: 100,000$.

Leverett F. 1902. Glacial formations and drainage features of the Erie and Ohio basins. Washington, USGS Monograph 41. $802 \mathrm{p}$.
Leverett F, Taylor FB. 1915. The Pleistocene of Indiana and Michigan and the history of the Great Lakes. U.S. Geological Survey Monograph 53.527 p.

Lewis CFM, Moore TCJ, Rea DK, Dettman DL, Smith AJ, Mayer LA. 1994. Lakes of the Huron basin: their record of runoff from the Laurentide Ice Sheet. Quat. Sci. Revs. 13:891-922.

Mickelson DM, Clayton L, Fullerton DS, Borns HWJ. 1983. The Late Wisconsin glacial record of the Laurentide Ice Sheet in the United States. In: Wright HEJ, editor. Late-Quaternary Environments of the United States, vol 1. Minneapolis: University of Minnesota Press. p. 3-37.

Mörner N-A, Dreimanis A. 1973. The Erie Interstade. Geol Soc Am Mem. 136:107-134.

Murray AS, Wintle AG. 2000. Luminescence dating of quartz using an improved single-aliquot regenerative-dose protocol. Radiation Measur. 32:57-73.

Murray AS, Wintle AG. 2003. The single aliquot regenerative dose protocol: potential for improvements in reliability. Radiation Measur. 37:377-381.

Prescott JR, Hutton JT. 1994. Cosmic ray contributions to dose rates for luminescence and ESR dating: large depths and long-term time variations. Radiation Measure. 23: 497-500.

Rasmussen SO, Andersen KK, Svensson AM, Steffensen JP, Vinther BM, Clausen HB, Siggaard-Andersen M-L, Johnsen SJ, Larsen LB, Dahl-Jensen D, and others. 2006. A new Greenland ice core chronology for the last glacial termination. J Geophys. Res. 111:DO6102.

Rodnight H. 2008. How many equivalent dose values are needed to obtain a reproducible distribution? Ancient TL. 26:3-9.

Shaw J, Archer J. 1978. Winter turbidity current deposits in Late Pleistocene glaciolacustrine varves, Okanagan Valley, British Columbia, Canada. Boreas. 7:123-130.

Sheriff RE. 1989. Geophysical Methods. Prentice-Hall. 605 p.

Smith ND, Ashley GM. 1985. Chapter 4 Proglacial lacustrine environment. In: Ashley GM, Shaw J, Smith ND, editors. Glacial Sedimentary Environments. Short Course No. 16. Tulsa, OK: Soc. Paleontol Min. p. 135-216.

Snowball I, Sandgren P, Petterson G. 1999. The mineral magnetic properties of an annually laminated Holocene lake-sediment sequence in northern Sweden. Holocene. 9:353-362.

Szabo JP, Angle MP, Eddy AM. 2011. Pleistocene glaciation of Ohio, USA. In Ehlers J, Gibbard PL, Hughes PD, editors. Quaternary Glaciations_-Extent and Chronology, Elsevier Developments in Quaternary Science 15:513-519.

Szabo JP, Carter CJ, Bruno PW, Jones EJ. 1988. Glacial and postglacial deposits of northeastern Ohio. Ohio J Sci. 88:66-74.

Totten SM. 1985. Chronology and nature of the Pleistocene beaches and wave-cut cliffs and terraces, northwestern Ohio. In Karrow PF, Calkin PE, editors. Quaternary Evolution of the Great Lakes. St. John's, Sp Pap 30. Geological Survey of Canada. p. 171-184.

Wintle AG, Murray AS. 2006. A review of quartz optically stimulated luminescence characteristics and their relevance in single-aliquot regeneration dating protocols. Radiation Measur. 41:369-391. 